\title{
Impact of Fundamental, Risk and Demography on Value of the Firm
}

\author{
Dompak Pasaribu \\ Lecturer, Methodist University of Indonesia, Jl. Hang Tuah No.8, Madras Hulu, Kota Medan, Sumatera Utara \\ 20112, Indonesia
}

\begin{abstract}
The purpose of this study is to examine the effect of the company's fundamentals (DER and ROA), Systematic risk (beta stocks) and population growth (PP) on firms value (PBV).The sampleswas food and beverage sub-sectors listed in Indonesia Stock Exchange. The sampling technique is purposive sampling. The data used annual data from 2010 to 2015. The analytical method used is multiple regression.The results of this research show that partially Debt Equity Ratio (DER), Return on Assets (ROA) and population growth (PP) positive and significant impact on the PBV while Systematic Risk (Beta Shares) not significant positive effect on the PBV.Simultaneously DER, ROA, Beta Stocks and PP significant effect on PBV. Value Adjusted R Square of 0.859 .
\end{abstract}

Keyword: Corporate Values (Price Book Value / PBV), Debt to Equity Ratio (DER), Return on Assets (ROA), Systematic Risk (Beta Equity) and Population Growth (PG).

\section{Introduction}

Usually, an enterprise has the primary goal of generating optimal profit and enhance shareholder value. For the achievement of the optimal profit, management becomes a potential to improve their welfare by the owner through additional compensation received by the Directorate. The leadership of the company's management will always try to encourage staff to improve its performance to achieve the optimal profit. However, for shareholders achievement of optimal profit is not the main focus, but the increase in a value of the company. Increasing the value of the company means an increase in shareholder value. For enterprises that listed on the Capital Market (Stock Exchange) the company's value can be mirrored or can be measured through the company's stock price in the stock market. In the literature of finance to date stock price can be determined by the Price to Book Value (PBV) Market to Book Ratio (MBR) Market to Book Assets Ratio, Market Value of Equity, Enterprise value (EV), Price Earnings Ratio (PER ) and Tobin's Q.

Measurement of the value of the company stock price using the Price to Book Value (PBV) could be done by comparing the stock price and the book value of shares. Market to Book Ratio (MBR), which compares the stock exchange price and book value of the shares. Market to Book Ratio Assets that market expectations about the value of the investment opportunities and the growth of the company which is the ratio of assets market value and book value of assets. Market Value of Equity is the market value of the business's equity according to the assessment of market participants. Enterprise value (EV) market capitalization value is calculated as market capitalization plus total debt plus minority interest and preferred shares minus total cash and cash equivalents. Price Earnings Ratio (PER) that is the price paid by the buyer is willing if the company is sold. While Tobin's $Q$ is the market value of a company by comparing the market value of businesses listed on the financial markets with a replacement value of the asset (asset replacement value) of the company. Of course, the above calculation of each method has advantages and disadvantages. However, it can be concluded if the stock price higher then it will be good for shareholders because it will increase its wealth when shares were sold. However, for potential investors in the capital market, high stock prices reflect that the shares were expensive so the possibility of a decision to buy or have to be postponed until the stock price down to touch the reasonable price they charge. Thus the attitude of investors which shows that investors in the capital market are rational, so the choice of investment by the investor will take into account the expected return will be accepted.

In portfolio theory, investors can only estimate the expected profit rate (expected return) and how far the possibility of actual future results may deviate from the anticipated results. Return proportional to risk means that if an investment opportunity has a high-profit potential risk is also high potential. In other words, the higher the risk of an investment opportunity, the higher the level of profit (return) is signaled by the investor (Jogianto, 2000). High stock prices make the company's value too high. The high value of the company will make the market believe not only on the company's performance today but also in the company's prospects in the future. According to Cheng (1997), the investor in selecting the type of capital market investment is influenced by fundamental and technical factors. Fundamental factors may include macroeconomic conditions and internal conditions of the company (financial performance). There are few of macroeconomic fundamentals such as inflation, interest rates exchange rates, a balance of trade and others. Internal factors are the company's 
performance as measured by financial ratios such as liquidity ratios, solvency, and profitability. External factors cannot be controlled nature by company whereas internal factors tend to be controlled by the Integration. Investors use technical factors such as historical data in making investment decisions concerning patterns of price movements, volume, and trends happening in the capital market. Investors in the capital market could be distinguished according to flow the investors believed, that is the flow of fundamental and technical streams.

Table 1: Fundamental Issuer Sector Food and Drink

\begin{tabular}{|l|l|l|l|l|}
\hline Issuer & Year & DER & ROA & PBV \\
\hline INDF & 2012 & 0,74 & 8,06 & 1,5 \\
\hline & 2013 & 1,04 & 4,38 & 1,51 \\
\hline & 2014 & 1,08 & 5,99 & 1,45 \\
\hline CEKA & 2012 & 1,22 & 5,68 & 0,8 \\
\hline & 2013 & 1,02 & 6,08 & 0,65 \\
\hline & 2014 & 1,39 & 3,19 & 0,87 \\
\hline DLTA & 2012 & 0,25 & 28,64 & 6,83 \\
\hline & 2013 & 0,28 & 31,2 & 8,99 \\
\hline & 2014 & 0,3 & 29,04 & 9,33 \\
\hline SKLT & 2012 & 0,93 & 3,19 & 0,96 \\
\hline & 2013 & 1,16 & 3,79 & 0,89 \\
\hline & 2014 & 1,16 & 4,97 & 1,36 \\
\hline
\end{tabular}

Based on the above table can be seen when the Return on Asset (ROA) INDF issue in 2014 amounted to $5.99 \%$, the PBV 2014 compared to 2013.The decrease in 2013 PBV of 1.51 to 1.45 in 2014. In contrast to the issues CEKA when ROA 2013 and 2014 by 6.08 down to 3.19 but PBV increased the year of 2013 by 0.65 to 0.87 in 2014, so is the issue DLTA, ROA in 2013 and 2014 respectively of 31.2 and 29.04 respectively but PBV in 2014 have increased the year of 2013 by 8.99 becomes 9.33 in 2014. The condition is contrary or inconsistent with the theory that when ROA increases, the value of companies in the PBV it will increase.

The research was conduct on food and beverage sub-sectors listed on the Indonesia Stock Exchange. This research only examines the influence of fundamental factors, systematic risk, and population growth to value companies in the sub-sectors of food and minimum listed on the Indonesia Stock Exchange for the years $2010-2015$

\section{A. The value of the company}

\section{Material and Method}

For investors increase the value of the business has a meaning as an increase in wealth. According to Fama (1978) the company's value will be reflected in its share price. The market price of shares of the company formed between buyers and sellers when transactions occur are called the company's market value because the price of the stock market is considered a reflection of the actual value of the business's assets. Theory of the firm examines how companies determine which combination of available resources optimally to generate value for the enterprise. The company's value would be easily measured by the time liquidated or sold through proxies' stock price, which stock market prices agreed upon buyers and sellers.

\section{B. Company Fundamentals}

The basic concept of connectedness thinking macroeconomic fundamentals, fundamentals, technical factors and the company's enterprise value is that the value of the company as a representation of the stock price is affected by these factors. Fundamental factors which are intended to be seen from its financial statements through the financial ratios of liquidity ratios, solvency and profitability. According to Roos, Westerfield, and Jordan (2004: 78), Financial Ratios is "the calculated relationship of a company's financial information and use for comparative purposes. Financial ratios often utilized in this study is the liquidity ratio, solvency and profitability ratios. Below are the explanation of the ratios.

1. Liquidity Ratio (Internal Liquidity)

Indicates the company's ability to pay short-term obligations through internal funding sources. The liquidity ratio, among others, the Current Ratio (Current Ratio). Current ratio shows the extent to which current assets cover current liabilities.

\section{Solvency ratios (Leverage)}

To measure the level of a company's ability to meet debt payment obligations can be done through:

a. Debt to Equity (D/E) Ratio

The comparison between total debt (total interest-bearing debt both long term and short term) and stockholders 'equity (shareholders' equity).

b. Long-Term Debt / Total Capital 
Analyzing the use of debt is by comparing total interest-bearing long-term debt (total long-term debt) to the long-run capital (total long-term capital).

\section{c. Debt Ratio}

Debt ratio shows the percentage of total assets financed by debt. Total debt includes short-term debt or long-term debt. The lower the debt ratio is lower financial leverage (through debt financing sources) and vice versa. The higher the debt ratio, the riskier for the company, (the possibility cannot pay the debt will be higher).

\section{Profitability Ratios}

Profitability ratio is a ratio showing the profitability of companies in the period. Profitability ratios consist of:

a. Gross Profit Margin

Measuring the effectiveness of the business in the use of material and labor resources to generate sales. The higher the gross margin, the better and the relatively lower cost of goods sold.

b. Basic Earning Power

Measuring basic capabilities the company's total assets to generate earnings before taxes and debt are affected, BEP obtained by dividing EBIT by total assets.

\section{c. Operating Profit Margin}

This ratio will inform profit from main activities (core business) and not influenced by other investments (such as revenue through an affiliate company or the sale of assets), interest (expense or interest income); as well as the taxation position.

\section{d. Net Profit Margin}

Net Profit Margin measures the percentage of the benefits from the company after paying all expenses incurred, including interest expense, taxes, and preferred stock dividends.

\section{e. Return On Assets (ROA)}

Return on Total Assets measures the success of the management uses its assets to generate earnings. Alternatively, measure the yields of companies acquired through utilization of its assets in total.

\section{Systematic Risk (Beta Equity)}

Each investment decision always involves two things, the level of risk and benefit ratio. The risk of having a positive and linear relationship with the level of expected return, the greater the risk borne by the investor. Risk is a deviation from the expected profit rate (expected return), and according to Jones (1991) risk is the possibility of earned income (actual return) in an investment will differ from expected revenues (expected return). The world's total risk capital market divides into two parts, namely the systematic risk and unsystematic risk. Investors who basically do not like the risk will pay more attention than the systematic risk. This is due to a systematic risk cannot be eliminated by diversifying the stock through a portfolio.

The size of the systematic risk is also called the beta coefficient $(\beta)$ is a measure of the sensitivity of individual profit levels (individual returns) a share to changes in market index gains (market return). While the unsystematic risk is part of the total risk stocks that are uniquely associated with the condition of the company or the industry in which it operates.

Beta can be used for a relative comparison of the systematic risk of stocks that are different, so it can be used by investors to estimate the risk of a stock. Stocks can be sorted by its beta. Stocks with high beta risk and vice versa is said to have stocks with low beta is said to have a low risk. Beta of a security can be calculated by the estimation technique that uses historical data. Beta is calculated based on this historical data can then be used to estimate future beta. In this study, beta is calculated is the market beta. Single Index Model is based on the observation that the price of a security to fluctuate in line with market price index. Return of a security and the return of a market index can be written with the relationship (Elton and Gruber, 1995):

$\mathrm{Ri}=\alpha \mathrm{i}+\beta \mathrm{i} . \mathrm{RMT}+\mathrm{e}$

Where:

$\mathrm{Ri}$ is a Securities Return Period; $\alpha \mathrm{i}$ is the expectation of the return value of the securities that are independent of market return; RM is the rate of return on the market index; $\beta \mathrm{i}$ is a beta, is the coefficient which measures the change in $\mathrm{Ri}$, as a result of changes in $\mathrm{RM}$; $\mathrm{e}$ is the error term

Return markets have valued beta 1 . Beta of a security that has a worth of 1.5 means that the changes in the market return of $1 \%$ would result in a change of return of such securities in the same direction at $1.5 \%$. Implicitly could mean that if the beta is stable, then the beta equity could also predicted to improve the reliability of the beta as an important component for the determination of return and investment strategies. 


\section{Population Growth}

Population growth is one of the important factors in the socio-economic problems in general and population issues in particular. Because in addition to the effect on the number and composition of the population will also affect the socio-economic conditions of a region or country and the world. Population growth is a good change of population increase or decline. The population growth rate is the rate of population of a region or country within a certain period and expressed as a percentage. The factors that affect the rate of population growth is among other Death (mortality), Birth (birthrate), and migration (mobility). The formula used in the search for the value of population growth are as follows:

Based on the formulation of the problem, objectives and study problems above, then the following is presented a framework of thinking that will be used in this research.

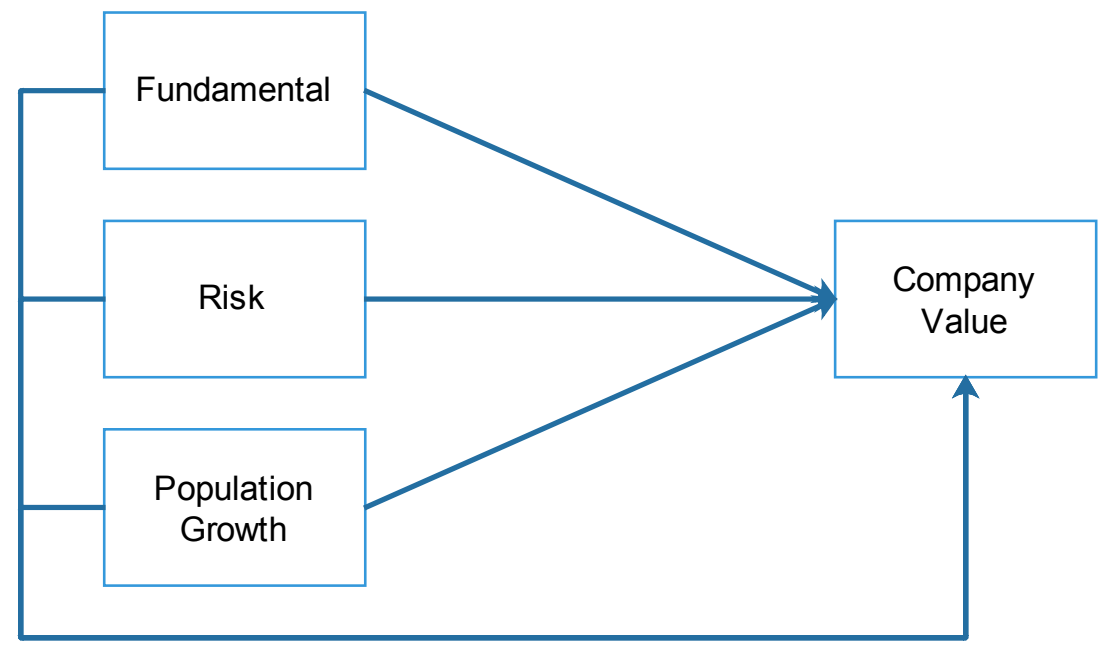

Fig 1. Framework Research

This study will examine the effect of the company's fundamental factors (DER and ROA), proxies' systematic risk (beta stock) and population growth is proxies by population growth from year to year during the period of observation. These factors were used as independent variables are supposed to influence the value of the company proxy PBV, the type of data that will be used in this research is secondary data of financial statements and ratios yearly from 2010 to 2015 were obtained from the Indonesia Stock Exchange, as well as the population in this study are all the group companies sub sectors of food and beverages that are listed on the Stock Exchange Indonesia by 15 issuers. The criteria for the sampling for this study are as follows:

1. The group company of food and beverage sub-sector listed in Indonesia Stock Exchange during the period of the financial year 2010-2015.

2. The company's shares are actively traded in the study period is for 5 years and are not suspended during the period of the financial year 2010-2015.

3. There are the financial statements during the period of the financial year the financial year 2010-2015

Next is to determine the type of the variables in this study, the variables used are:

1. Dependent Variable (Variable Y) is a value company that is proxies by PBV.

2. Independent Variable (Variable X) is (1) fundamentals of the company proxy DER (X1) and Return on Assets (ROA) (X2), (2) Risks Systematic proxies Beta Stocks (X3), (3) a proxy Population Growth the growth rate or population of productive age $15 \mathrm{sd} .60$ years (X4)

The operational definition of the variables used in this study can be seen as follows:

Table 2: Definition Variable

\begin{tabular}{|c|c|c|c|c|}
\hline No. & Variable & Definition & Scale & Measurement \\
\hline 1. & $\begin{array}{l}\text { Company value } \\
\text { (measured by PBV) }\end{array}$ & $\begin{array}{l}\text { The ratio is used to measure } \\
\text { the performance of the stock } \\
\text { market to book }\end{array}$ & Ratio & \\
\hline 2. & $\begin{array}{l}\text { Debt to Equity } \\
\text { Ratio (DER) }\end{array}$ & $\begin{array}{l}\text { Comparison between total } \\
\text { debt to total equity }\end{array}$ & Ratio & \\
\hline 3. & $\begin{array}{lll}\text { Return } & \text { On Asset } \\
\text { (ROA) } & & \end{array}$ & $\begin{array}{l}\text { The ratio between profits after } \\
\text { tax to total assets. }\end{array}$ & Ratio & \\
\hline 4. & $\begin{array}{l}\text { Systematic risk (as } \\
\text { measured by Beta }\end{array}$ & $\begin{array}{l}\text { Measurement } \\
\text { volatility of a security or }\end{array}$ & & \\
\hline
\end{tabular}




\begin{tabular}{|l|l|l|l|l|}
\hline Stocks) & $\begin{array}{l}\text { portfolio returns to market } \\
\text { return. }\end{array}$ & $\begin{array}{l}\text { The growth of the } \\
\text { productive age } \\
\text { population (ages 15 } \\
\text { to. } 60 \text { years) }\end{array}$ & $\begin{array}{l}\text { Calculating population growth } \\
\text { by comparing the population } \\
\text { at the end of the reduced } \\
\text { population at the beginning of } \\
\text { the period in the early } \\
\text { population at the beginning of } \\
\text { the period. }\end{array}$ & \\
\hline
\end{tabular}

\section{Result and Discussion}

The average value of DER of 1.1767 indicates the ability of the company's own capital as collateral all the debts of the company were positive during the years 2010 to 2015 with a maximum value of 8.40 and a minimum of $\$ 0.00$.The standard deviation of 1.00596 DER larger than the average value of 1.1767.

The average value of 14.6661 ROA shows the ability of the company's own capital as collateral all the debts of the company were positive during the years 2010 to 2015 with a maximum value of 143.53 and a minimum of 8.20. ROA amounted to 27.01315 standard deviation greater than the average value of 14.6661 .

The average value of systematic risk measured by beta coefficient $(\beta)$ is equal to -0.1077 with maximum values of 102.74 and a minimum beta of -37.65 . Maximum Beta is beta more than one $(\beta>1)$, this happens to stocks that tend to move in the market and a very large movement. Stocks with a beta of more than one of the less stable or more volatile than the average stock, this stock is referred to as aggressive stocks. The standard deviation of 12.59724 beta greater than the mean value of -0.1077 . This shows that at that time shares in companies involved in the sector in the field of food and beverage consumption tends to move in the market but not too much movement.

The average value of 0.1718 with the Population Growth maximum value of 0.82 and a minimum of 0.02 . The standard deviation of 0.25378 Population growth is greater than the average value of 0.1718 . With the standard deviation value which is considerably larger than the average value, indicating that variation Population Growth of the company that made a large enough sample. The average value of 0.1718 population growth which means that in general that the greater the amount of population growth, the company moving consumer food and beverage sector to be one positive signal for the company, for more detailed results can be seen in the following table:

Table 3

\begin{tabular}{|l|l|l|l|l|l|}
\hline \multicolumn{6}{|l|}{ Descriptive Statistics } \\
\hline & $\mathrm{N}$ & Mean & Std. Deviation & Minimum & Maximum \\
\hline DER & 88 & 1,1767 & 1,00596 &, 00 & 8,40 \\
\hline ROA & 88 & 14,6661 & 27,01315 & $-8,20$ & 143,53 \\
\hline BETASHARE & 88 &,- 1077 & 12,59724 & $-37,65$ & 102,74 \\
\hline PG & 88 &, 1718 &, 25378 &, 02 &, 82 \\
\hline PBV & 88 & 4,6735 & 8,50964 &, 50 & 48,67 \\
\hline
\end{tabular}

1. Classic assumption test

Table 4

\begin{tabular}{|l|l|l|}
\hline \multicolumn{2}{|l|}{ One-Sample Kolmogorov-Smirnov Test } \\
\hline \multicolumn{2}{|l|}{} & Unstandardized Residual \\
\hline $\mathrm{N}$ & Mean & 88 \\
\hline \multirow{2}{*}{ Normal Parameters } & Stb &, 0000000 \\
\hline \multirow{2}{*}{ Most Extreme Differences } & Std. Deviation & 3,11932992 \\
\cline { 2 - 3 } & Absolute &, 114 \\
\cline { 2 - 3 } & Positive &, 110 \\
\cline { 2 - 3 } & Negative &,- 114 \\
\hline Kolmogorov-Smirnov Z & 1,066 \\
\hline Asymp. Sig. (2-tailed) &, 206 \\
\hline
\end{tabular}

Based on Table 4 One Sample Kolmogorov-Smirnov Test Normal Distribution. From the results obtained Asymp. Sig (2-tailed) consisting of DER, ROA, beta stock and population growth have Asymp value sig (2-tailed) was $0.206>0.05$ thus it can be concluded that the data were normally distributed.Here is a test multicollinearity of the independent variables, as below:

Table 5: Test Multicolinearity

\begin{tabular}{ll|l|}
\multicolumn{2}{c}{ Table 5: Test Multicolinearity } \\
\cline { 2 - 3 } & \multicolumn{1}{c|}{ Collinearity Statistics } \\
\hline DOI: $10.9790 / 5933-0802040916$ & www.iosrjournals.org & $5 \mid$ Page
\end{tabular}




\begin{tabular}{|l|l|l|l|}
\hline \multicolumn{2}{|c|}{} & Tolerance & VIF \\
\hline \multirow{4}{*}{1} & (Constant) & & \\
\cline { 2 - 4 } & DER &, 935 & 1,070 \\
\cline { 2 - 4 } & ROA &, 770 & 1,300 \\
\cline { 2 - 4 } & BETASAHAM &, 767 & 1,304 \\
\cline { 2 - 4 } & PG &, 989 & 1,011 \\
\hline
\end{tabular}

Based on the test results and Tolerance VIF indicates that consistency Tolerance value above $10 \%$ and consistency VIF under 10. This indicates that the independent variable in this research was not correlated or not found a correlation between independent variables, so that the model does not contain multicoloniarity therefore models this regression can be used.

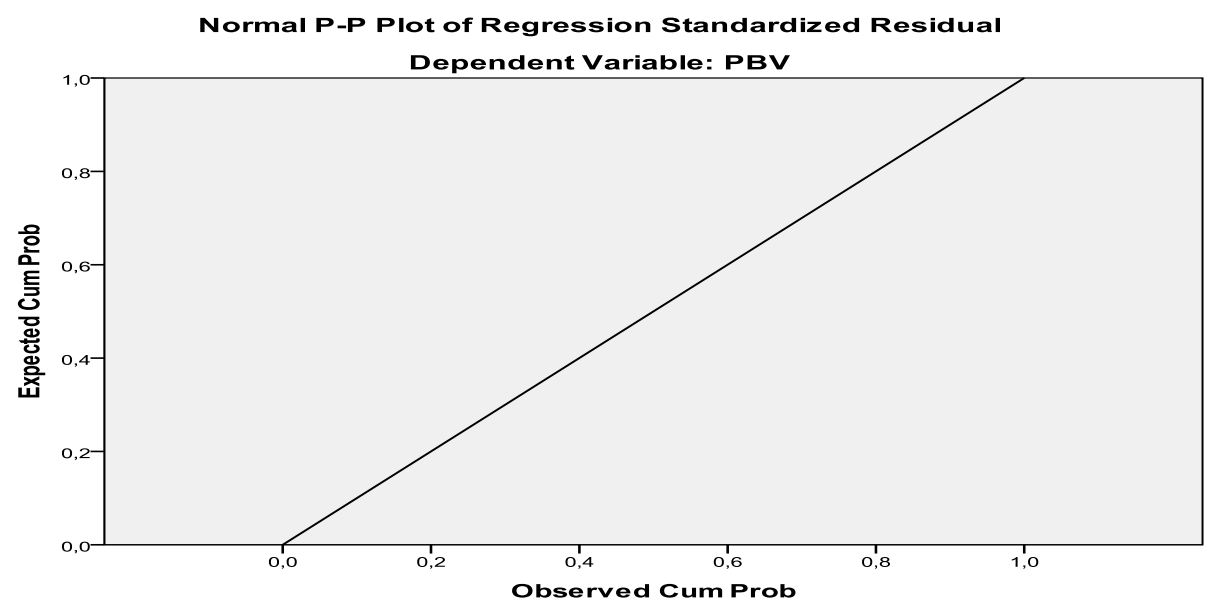

Fig 2. Test Heteroskidastity

Based on the figure 2 it can be seen that the data sample used to follow the linear line so the images showed that there is no Heteroskidastity used in the regression model.

Table 6: Watson Autocorrelation Test -Durbin

\begin{tabular}{|c|c|c|l|l|}
\hline Dl & $\mathrm{dU}$ & $\mathrm{D}-\mathrm{W}$ Count & \multicolumn{1}{c|}{ Result } & \multicolumn{1}{c|}{ Description } \\
\hline 1,5597 & 1,7493 & 1,773 & $\begin{array}{l}\mathrm{dU}<\mathrm{DW}_{\text {coun }}<4-\mathrm{dU} \\
\text { or } 1,7493<1,773<2,250\end{array}$ & $\begin{array}{l}\text { There is no } \\
\text { autocorrelation }\end{array}$ \\
\hline
\end{tabular}

Based on Table 6 values obtained range dU $<$ DW-count $<4$-dU or $1.7493<1.773<2.250$, which means that there is no correlation between a period $t$ with the previous period, making feasible the regression model used 2. Results of Multiple Linear Regression

Table 7: Estimated Regression

\begin{tabular}{|c|c|c|c|c|c|c|}
\hline & \multirow[t]{2}{*}{ Model } & \multicolumn{2}{|c|}{ Unstandardized Coefficients } & \multirow{2}{*}{$\begin{array}{c}\begin{array}{c}\text { Standardized } \\
\text { Coefficients }\end{array} \\
\text { Beta } \\
\end{array}$} & \multirow[t]{2}{*}{$\mathrm{t}$} & \multirow[t]{2}{*}{ Sig. } \\
\hline & & B & Std. Error & & & \\
\hline \multirow[t]{5}{*}{1} & (Constant) & $-2,737$ &, 619 & & $-4,421$ &, 000 \\
\hline & DER & 2,920 & ,352 & ,345 & 8,294 &, 000 \\
\hline & ROA & 238 &, 014 & ,756 & 16,483 &, 000 \\
\hline & BETASHARE &, 053 &, 031 & 079 & 1,713 &, 091 \\
\hline & PG & 2,837 & 1,357 & 085 & 2,091 &, 040 \\
\hline
\end{tabular}

Based on table 7 above can be created regression equation as follows:

Stock price $=0,345 D E R+0,756 R O A+0,079$ BETA SHARE + 0,85PG

Multiple linear regression equation above can be seen that the coefficient of 0.756 ROA is an indicator that most affect PBV. The following are the regression coefficients of each indicator in the regression model:

a. DER coefficient value of 0.345 (positive) means that statistically DER positive and significant influence $(0,000)$ against PBV. The results of this test means that if DER rose $1 \%$, the PBV will rise by 0.345 $(34.5 \%)$. In other words, stock prices will rise if the DER ride. 
b. ROA coefficient value of 0.756 (positive) means that statistically ROA positive and significant influence $(0,000)$ against PBV. The results of this test means that if ROA rose $1 \%$, the PBV will rise by $0.756(76 \%)$. In other words PBV will rise if ROA rose.

c. Beta Share coefficient value of 0.079 (positive) means that statistically Beta Stocks positive effect was not significant (0.091) against PBV. The results of this test means that if Beta Stocks rose 1\%, the PBV will increase by $0.079(8 \%)$. In other words PBV will rise if BETA STOCKS rose.

d. PG coefficient value of 0.085 (positive) means that statistically significant and positive impact PG $(0,040)$ against PBV. The results of this test means that if the PG rose by $1 \%$, then the PBV will rise by $0,085(9 \%)$. In other words PBV will rise if the PG rise

3. F Test (Simultaneous Test)

F test results will clarify whether all the independent variables together have a significant effect on the dependent variable. $\mathrm{F}$ test results can be seen in the following table:

Table 8 Simultaneous Test (Test Statistic F)

\begin{tabular}{|c|l|l|l|}
\hline $\mathrm{F}$ & Sig (P-Value) & Criteria Testing & Description \\
\hline 133,675 &, $000^{\mathrm{a}}$ & $\mathrm{P}<0,05$ & Significant \\
\hline
\end{tabular}

4. T-Test (Partial Test)

The following are the results of testing the hypothesis with $\mathrm{t}$ test (partial test), as below:

Table 9 T-Test

\begin{tabular}{|c|c|c|c|c|c|c|}
\hline \multirow{2}{*}{\multicolumn{2}{|c|}{ Model }} & \multicolumn{2}{|c|}{$\begin{array}{l}\text { Unstandardized } \\
\text { Coefficients }\end{array}$} & \multirow{2}{*}{$\begin{array}{c}\begin{array}{c}\text { Standardized } \\
\text { Coefficients }\end{array} \\
\text { Beta }\end{array}$} & \multirow[t]{2}{*}{$\mathrm{T}$} & \multirow[t]{2}{*}{ Sig. } \\
\hline & & $\mathrm{B}$ & Std. Error & & & \\
\hline \multirow[t]{5}{*}{1} & (Constant) & $-2,737$ & ,619 & & $-4,421$ & ,000 \\
\hline & DER & 2,920 & ,352 & ,345 & 8,294 &, 000 \\
\hline & ROA & ,238 &, 014 & ,756 & 16,483 &, 000 \\
\hline & BETASHARE &, 053 &, 031 & 079 & 1,713 &, 091 \\
\hline & PG & 2,837 & 1,357 &, 085 & 2,091 &, 040 \\
\hline
\end{tabular}

According to the table 9 it is known that:

a. DER has a significance value of 0.000 with 0.345 coefficient value (positive). Because the significance value (sig.) 0,000 less than 5\%, it can be stated that the DER positive and significant effect on the PBV.

b. ROA has a significance value of 0.000 with 0.756 coefficient value (positive). Because the significance value (sig.) 0,000 less than 5\%, it can be stated that ROA positive and significant effect on the PBV.

c. Beta shares have a significance value 0.090 with 0.079 coefficient value (positive). Because the significance value (sig.) .090 greater than $5 \%$, it can be stated that the positive effect of beta stocks are not significant to the PBV.

d. PG (population growth) have a significance value 0,040 with coefficient of 0.085 (positive). Because the significance value (sig.) 0,040 less than 5\%, it can be stated that the PG positive and significant effect on the PBV

5. Coefficient of Determination

The coefficient of determination measures how far the model's ability to explain the variations of the dependent variable

Table 10 Coefficient of Determination

\begin{tabular}{|l|l|l|l|}
\hline $\mathrm{R}$ & R Square & Adjusted R Square & $\begin{array}{l}\text { Std. Error of the } \\
\text { Estimate }\end{array}$ \\
\hline, $930^{\mathrm{a}}$ &, 866 &, 859 & 3,19361 \\
\hline
\end{tabular}

According to the table 10 it is known that the value of Adjusted R Square of 0.859 it means that the variation of the independent variables are able to explain $0.859(86 \%)$ dependent variable, while the rest of 0.14 $(14 \%)$ is explained by other variables not included in the regression model. While the correlation coefficient $(\mathrm{R})$ of $0.930(093 \%)$ explain the very strong relationship between the independent variables and the dependent variable.

\section{Conclusion}

Based on the analysis and discussion it can be concluded on this study that the statistical test results on hypothesis 1 indicates that the Debt Equity Ratio (DER) positive and significant influence to Price to Book Value (PBV). The higher the debt will increase corporate value throughout the growth of debt or the debt risk management as well managed. Thus the hypothesis 1 is accepted, followed by a statistical test on hypothesis 2 
shows that the Return on Asset (ROA) positive and significant influence to Price to Book Value (PBV. The higher the ROA will increase the company's value for ROA shows management capabilities generate profitability by using assets there. thus the hypothesis 2 is accepted, statistical testing on hypothetical 3 shows that the risk of Systematic (Beta shares) positive effect is not significant to Price to Book value (PBV. the higher Beta stocks will increase the company's value (PBV). it is not according to the theory. thus the hypothesis 3 is rejected, and the final test is statistically above hypothesis 4 shows that the growth of population (PP) positive and significant influence to Price to Book value (PBV). the higher the PP will increase the company's revenue will further increase the value of the company (PBV). Thus the hypothesis 4 is rejected, so it can be concluded that simultaneous DER, ROA, Beta Stocks and PP significant effect on PBV, Adjusted R Square of 0.859.

\section{References}

[1]. S. Ozlen, "The Effect Of Company Fundamentals On Stock Values," European Researcher, Vol. 71, No. 3, Pp. 595-602, 2014.

[2]. A. Nurhakim S, I. Yunita And A. Iradianty, "The Effect Of Profitability And Inflation On Stock Return At Pharmaceutical Industries At Bei In The Period Of 2011-2014," Asia Pacific Institute Of Advanced Research (Apiar), Vol. 2, No. 2, Pp. 202-210, 2016.

[3]. C. I. Enekwe, C. I. Agu And E. K. Nnagbogu, "The Effect Of Financial Leverage On Financial Performance: Evidence Of Quoted Pharmaceutical Companies In Nigeria.," Iosr Journal Of Economics And Finance (Iosr-Jef), Vol. 5, No. 3, Pp. 17-25, 2014.

[4]. A. H. Dita And I. Murtaqi, "The Effect Of Net Profit Margin, Price To Book Value And Debt To Equity Ratio To Stock Return In The Indonesian Consumer Goods Industry," Journal Of Business And Management, Vol. 3, No. 3, Pp. 305-315, 2014.

[5]. D. Martani, Mulyono And R. Khairurizka, "The Effect Of Financial Ratios, Firm Size, And Cash Flow From Operating Activities In The Interim Report To The Stock Return," Chinese Business Review, Vol. 8, No. 6, Pp. 44-55, 2009.

[6]. K. Taani And M. H. H. Banykhaled, "The Effect Of Financial Ratios, Firm Size And Cash Flows From Operating Activities On Earnings Per Share: (An Applied Study: On Jordanian Industrial Sector)," International Journal Of Social Sciences And Humanity Studies, Vol. 3, No. 1, Pp. 197-205, 2011.

[7]. "Www.Idx.Co.Id," [Online]. 